\title{
Case report of one month and 15 days old baby with type $\mathrm{V}$ hyperlipoproteinemia (HLP)
}

\author{
Shabnam Dildar ${ }^{*}$ and Tahir Sultan Shamsi
}

\begin{abstract}
Background: Most of the patients with type 1 and $V$ hyperlipoproteinemia (HLP) present with symptoms and signs of acute pancreatitis due to marked elevation of triglycerides, but this baby presented with a chest infection, which was later diagnosed as type V HLP on laboratory workup.

Case presentation: We report a case of a 1 month and 15 days old baby boy, product of 2-nd degree consanguinity admitted to a nearby hospital with complaints of refusal to feed, cough and excessive crying. On examination his heart rate was 102 beats/min, respiratory rate was 55 breaths/min and temperature was within the normal range, provisional diagnosis of Pneumonia was made. His samples were tested at our laboratory, the lipid Profile at age of 1 month 15 days showed total cholesterol (TC) of $1400 \mathrm{mg} / \mathrm{dl}$ reference range $(\mathrm{RR}<200 \mathrm{mg} / \mathrm{dl})$, triglycerides (TG) of $>885 \mathrm{mg} / \mathrm{dl}$ after dilution it was $31,400 \mathrm{mg} / \mathrm{dl}(\mathrm{RR}<150 \mathrm{mg} / \mathrm{dl})$, High density Cholesterol (HDL) of $35 \mathrm{mg} / \mathrm{dl}(\mathrm{RR}>40 \mathrm{mg} / \mathrm{dl}$ ) and low density cholesterol (LDL) of $200 \mathrm{mg} / \mathrm{dl}(\mathrm{RR}<100 \mathrm{mg} / \mathrm{dl})$. The patient's blood sample was grossly milky and lipemic in appearance. A "Refrigerator test" was performed after overnight storage of the sample in refrigerator at $4^{\circ} \mathrm{C}$, which gave a creamy layer at the top and clear infranatant due to caking of the Chylomicrons. Lipoprotein electrophoresis performed 1 month later showed Chylomicrons of 4.7\% (RR 0-2\%), Prebeta lipoproteins of 51.5\% (RR 5-22\%), beta lipoproteins of 16.5\% (RR 39-70\%) and alpha of 27.3\% (RR 23-53\%). Initially he was diagnosed as type $1 \mathrm{HLP}$, but later on he was correctly diagnosed as type V HLP. Cholestyramine (Questran sachet) powder was started at a dose of $100 \mathrm{mg} / \mathrm{kg}$ on ti..d basis with NAN-1 formula Milk at the age of 1 month and 15 days. On follow up, detailed advices regarding the weaning food was given to the mother (using olive oil in cooking, giving proteins and avoiding heavy fatty meals). His lipid profile was repeated at age of 3 months, which showed some improvement, his TGs were $1986 \mathrm{mg} / \mathrm{dl}$ and TC $105 \mathrm{mg} / \mathrm{dl}$.
\end{abstract}

Conclusion: There is no universal diagnostic criterion for diagnosing Type V HLP, most likely, due to a scanty literature on this disorder. It stimulated us to report this case so that our findings may help for a timely diagnosis of the affected patients.

Keywords: Type I and V hyperlipoproteinemia, Triglycerides (TG), Refrigerator test, Cholestyramine, Pre-beta lipoproteins, Beta lipoproteins

\footnotetext{
* Correspondence: shabnam.dildar@yahoo.com

Department of Pathology, National Institute of Blood disease and Bone

Marrow Transplantation (NIBD), ST 2/A Block 17 Gulshan-e-iqbal KDA Scheme

24, Karachi 74800, Pakistan
}

(c) The Author(s). 2020 Open Access This article is distributed under the terms of the Creative Commons Attribution 4.0 International License (http://creativecommons.org/licenses/by/4.0/), which permits unrestricted use, distribution, and reproduction in any medium, provided you give appropriate credit to the original author(s) and the source, provide a link to the Creative Commons license, and indicate if changes were made. The Creative Commons Public Domain Dedication waiver (http://creativecommons.org/publicdomain/zero/1.0/) applies to the data made available in this article, unless otherwise stated. 


\section{Background}

Most of the patients with type 1 and $\mathrm{V}$ hyperlipoproteinemia (HLP) present with symptoms and signs of acute pancreatitis due to marked elevation of triglycerides levels, but this baby presented with a chest infection instead which was later diagnosed as type V HLP on the laboratory workup.

Lipids, such as cholesterol and triglycerides, are insoluble in plasma and are therefore transported in the plasma via Lipoproteins. Lipoproteins consist of esterified and unesterified cholesterol, triglycerides, phospholipids, and proteins [1]. Lipoproteins are complex molecules consisting of central hydrophobic lipids primarily cholesterol esters and triglycerides surrounded by free cholesterol, phospholipids, and apolipoproteins. Lipoproteins are classified into seven classes based on their size, lipid composition and apolipoproteins; these are Chylomicrons, Chylomicrons remnants, VLDL, IDL, LDL, HDL, and Lpa [2]. The adult treatment panel (ATP) III, National Lipid Association and the National Cholesterol Education Program (NCEP), and the National heart, lung and blood institute of National Institutes of Health (NIH) in 2001 have set the cutoffs for total Cholesterol, with $<200 \mathrm{mg} / \mathrm{dl}$ being optimal, $200-239 \mathrm{mg} / \mathrm{dl}$ as borderline high, $\geq 240 \mathrm{mg} / \mathrm{dl}$ as high. Triglyceride: $<150 \mathrm{mg} / \mathrm{dl}$ is optimal, $150-199 \mathrm{mg} / \mathrm{dl}$ is borderline high, $200-499 \mathrm{mg} / \mathrm{dl}$ is high and $\geq 500 \mathrm{mg} / \mathrm{dl}$ is considered as very high. LDL cholesterol should be < $100 \mathrm{mg} / \mathrm{dl}$, level $100-129 \mathrm{mg} / \mathrm{dl}$ is above desirable, level is $130-159 \mathrm{mg} / \mathrm{dl}$ borderline high, level $160-189 \mathrm{mg} / \mathrm{dl}$ is high and $\geq 190 \mathrm{mg} / \mathrm{dl}$ is very high. Whereas HDL cholesterol range for males is $\geq 40 \mathrm{mg} / \mathrm{dl}$ and that for females is $\geq 50 \mathrm{mg} / \mathrm{dl}[3,4]$.

Lipid disorders are of two types, primary and secondary. Primary dyslipidemias occur due to an increase production or decreased removal of lipoproteins; whereas secondary dyslipidemias occur due to an abnormality in either the lipoprotein itself or in the lipoprotein receptors. A well recognized classification system of Fredrickson and World Health Organization (WHO), International Classification of Diseases (ICD) classifies Hyperlipoproteinemia (HLP) phenotypes based on the pattern of the lipoprotein fractions. Fredrickson type $\mathrm{V}$ HLP is also called as hyperchylomicronemia late onset, Hyperchylomicronemia with hyperprebetalipoproteinemia, familial Hyperlipemia combined fat and carbohydrate induced hyperlipemia, mixed Hyperlipidemia type $\mathrm{V}$ and Type V HLP. Increased Chylomicrons levels are present in Frederickson type 1 and type 5 HLP [5-7]; these gives a milky "latescent" or "lipemic" appearance to the blood sample, due to the presence of increased Chylomicrons (CM) which floats in the blood and give a creamy appearance to the supernatant [8-11]. Type 1 HLP occurs due to the deficiency of extra hepatic lipoprotein lipase (LPL) enzyme or its cofactor apolipoproteins C-II (Apo-II), this insufficiency or deficiency causes marked elevation of TG rich plasma Chylomicrons $[12,13]$. Whereas etiology of type V HLP is complex with variable inheritance and it develop in genetically susceptible individuals. Both types (HLP 1 and 5) have elevated Chylomicrons, which gives a creamy top layer to the blood sample. Type V has elevated VLDL Cholesterol with turbid infranatant and the frequency of this disorder is about 5\% [14]. Whereas type 1 doesn't have VLDL elevation, it has clear infranatant and frequency of this disorder is less than $1 \%[14,15]$.

\section{Case presentation}

We report a case of a 1 month 15 days old baby boy, he was admitted to a nearby hospital with the provisional diagnosis of Pneumonia and his sample was sent to our hospital for laboratory testing. The blood sample on gross examination appeared milky, and we therefore took a detailed history from the parents with their consent. He was the product of 2nd-degree consanguinity, first child with no sibling's, born full term via spontaneous vaginal delivery (SVD) with a normal antenatal history. His developmental history was normal and was up to date on all the immunizations. The past medical and the family history were not significant for Hyperlipidemia.

He was admitted to the emergency ward of a nearby hospital with a history of refusal to feed, cough and excessive cry. On examination his heart rate was 102 beats $/ \mathrm{min}$, respiratory rate was 55 breaths $/ \mathrm{min}$, temperature was $37^{\circ} \mathrm{C}$ and oxygen saturation was $98 \%$.

The laboratory testing revealed the following: Complete blood count (CBC) done on XN-1000 Sysmex hematology analyzer by flow cytometry technique showed hemoglobin of 6.8, White blood cell count of 15.8 and platelets of 161 . The sample that was obtained.

appeared milky and lipemic and therefore, he was also screened for Hyperlipidemia. Lipid profile was done by enzymatic method on Cobasc-311 analyzer; its analytical measuring range (AMR) for triglycerides is $8.85 \mathrm{mg} / \mathrm{dl}$ to $885 \mathrm{mg} / \mathrm{dl}$. Analyzer gave the result of $>885 \mathrm{mg} / \mathrm{dl}$, since the patients' physician requested for the exact levels, the sample was rerun, and the results were reported after manual serial dilutions of 1: 50 and multiplication with factor. HDL and LDL levels were performed by the Homogeneous enzymatic colorimetric method on Cobas c-311 analyzer with Analytical Measurement Range (AMR) of $3.09-150 \mathrm{mg} / \mathrm{dl}$ and $2-548 \mathrm{mg} / \mathrm{dl}$ respectively. Serum amylase and lipase was done on Erba XL-200 by enzymatic method, while liver function tests were done by IFCC kinetic method on the Cobas c-311 analyzer as shown in Table 1. 
Table 1 Routine laboratory investigation of patient

\begin{tabular}{lll}
\hline Routine lab investigations & Results & Reference range \\
\hline $\mathrm{Hb}(\mathrm{g} / \mathrm{dl})$ & 6.8 & $9.4-13.0 \mathrm{~g} / \mathrm{dl}$ \\
Total Wbc count $\left(\mathrm{X} 10^{9} / \mathrm{L}\right)$ & 15.8 & $5.00-15.0 \times 10^{9} / \mathrm{L}$ \\
Platelets $\left(\mathrm{X} 10^{9} / \mathrm{L}\right)$ & 161 & $210-650 \times 10^{9} / \mathrm{L}$ \\
ALT or SGPT $(\mathrm{U} / \mathrm{L})$ & 05 & $<45 \mathrm{U} / \mathrm{L}$ \\
ALP $(\mathrm{U} / \mathrm{L})$ & 477 & $122-469 \mathrm{U} / \mathrm{L}$ \\
Total Bilirubin $(\mathrm{mg} / \mathrm{dl})$ & 0.20 & $0-2.0 \mathrm{mg} / \mathrm{dl}$ \\
Direct Bilirubin $(\mathrm{mg} / \mathrm{dl})$ & 0.69 & $0-0.2 \mathrm{mg} / \mathrm{dl}$ \\
Lipase $(\mathrm{U} / \mathrm{L})$ & 35.8 & $<38 \mathrm{U} / \mathrm{L}$ \\
Amylase $(\mathrm{U} / \mathrm{L})$ & 26 & $<100 \mathrm{U} / \mathrm{L}$ \\
HIV 1 and 2 & Non-Reactive & Cut off $<1$ \\
HepB-sAg & Non-Reactive & Cut off $<1$ \\
Anti-HCV Ab & Non-Reactive & Cut off $<1$ \\
Syphilis & Non-Reactive & Cut off $<1$ \\
\hline
\end{tabular}

Electrocardiography showed severely hypertrophied normal sized left ventricle with a normal systolic function likely due to non-obstructive hypertrophic cardiomyopathy. Age wise lipid profile is shown in Table 2. A" refrigerator test" was performed after overnight storage of blood sample in the refrigerator at a temperature of $4{ }^{\circ} \mathrm{C}$, which revealed the appearance of creamy supernatant due to the caking of Chylomicrons (shown in Fig. 1). Other tests like Apolipoproteins B (Apo B), ApoA-V, lipoprotein (a) Lp(a), ApoC-11 and Glycosylphosphatidyl inositol anchored high density lipoprotein binding protein 1 (GPIHBP1) could not be done because of unavailability of these tests in our laboratory and the country at large, and patient's parents were reluctant to send the samples abroad because of financial limitations. Lipid lowering agents were not started as we could not find any recommendations for its use below 3 months of age. Initially he was diagnosed as type 1 HLP, but later at the age of 2 months and 16 days his lipoprotein electrophoresis was done which showed elevated levels of VLDL or Pre-beta lipoproteins 51.5\% (RR 5-22\%) and Chylomicrons 4.7\% (RR 0-2\%) shown in Table 3. Cholestyramine (Questran sachet) powder was started at dose of $100 \mathrm{mg} / \mathrm{kg}$ on t.i.d basis with NAN 1 formula milk at the age of 1 month and 15 days and on follow up visit detailed weaning food advices were given to the mother (use of olive oil during cooking of weaning food, giving

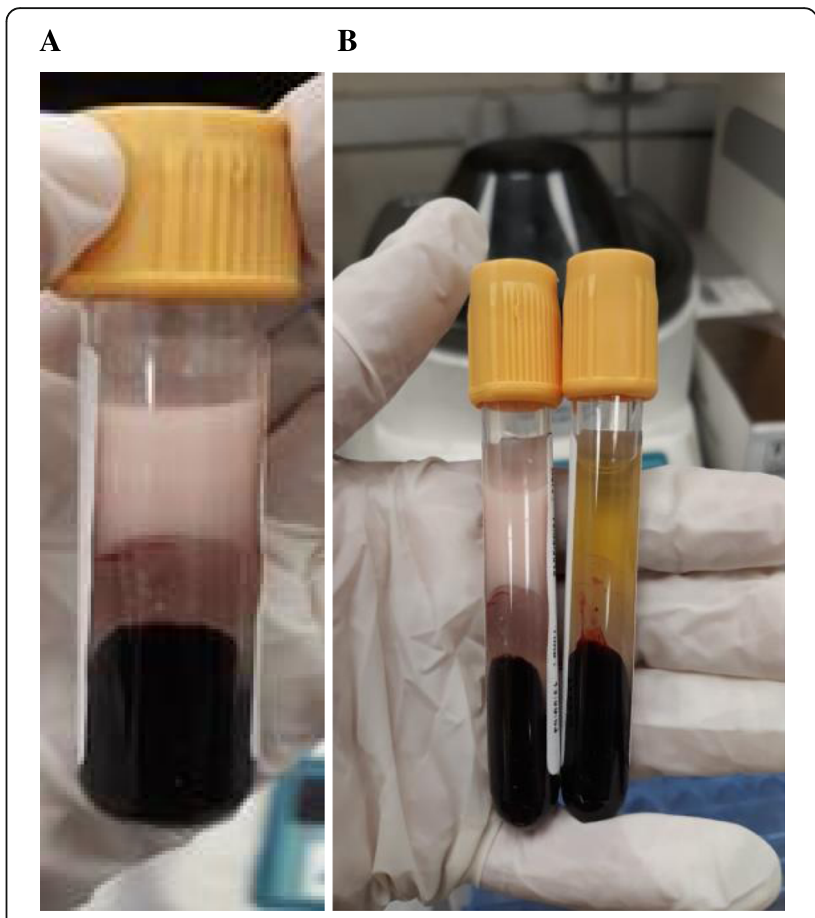

Fig. 1 a Patient's sample with creamy supernatant when refrigerated overnight at $4^{\circ} \mathrm{C}$. b Patient's sample along with normal sample

protein and avoiding a diet consisting of fatty meals was advised). His lipid profile was checked at age of 3 months showed TGs $1986 \mathrm{mg} / \mathrm{dl}$ (RR $<150 \mathrm{mg} / \mathrm{dl})$ TC was $105 \mathrm{mg} / \mathrm{dl}(\mathrm{RR}<200 \mathrm{mg} / \mathrm{dl})$, HDL was $5 \mathrm{mg} / \mathrm{dl}(\mathrm{RR}$ $>40 \mathrm{mg} / \mathrm{dl})$ and LDL was $2 \mathrm{mg} / \mathrm{dl}(\mathrm{RR}<100 \mathrm{mg} / \mathrm{dl})$ as shown in Table 2.

\section{Discussion and conclusion}

Type V hyperlipoproteinemia (HLP) has many names including hyperchylomicronemia late onset, Hyperchylomicronemia with hyperprebetalipoproteinemia, familial Hyperlipemia combined fat and carbohydrate induced, Hyperlipemia mixed, Hyperlipidemia type V and Hyperlipoproteinemia type 5 .

In this case, a ratio of triglycerides to total cholesterol (TG/TC) was $22.4 \mathrm{mg} / \mathrm{dl}$ (reference range $5 \mathrm{mg} / \mathrm{dl}$ ). A ratio of total triglycerides to total cholesterol (TG/TC) above 2.2 (if measured in $\mathrm{mmol} / \mathrm{l}$ ) or above 5 (in $\mathrm{mg} / \mathrm{dl}$ )

Table 2 Lipid profile at 1 month 15 days, 2 and 3 month

\begin{tabular}{lllll}
\hline Biochemical investigation & Age of 1 month 15 days & 2 months & 3 months & Reference range $(\mathrm{mg} / \mathrm{dl})$ \\
\hline Total Cholesterol $(\mathrm{mg} / \mathrm{dl})$ & 1400 & 450 & 105 & $<200$ \\
Triglycerides $(\mathrm{mg} / \mathrm{dl})$ & 31,400 & 2300 & 1986 & $<150$ \\
HDL $(\mathrm{mg} / \mathrm{dl})$ & 35 & 70 & 05 & $<40$ \\
LDL $(\mathrm{mg} / \mathrm{dl})$ & 200 & 200 & 02 & $<100$ \\
\hline
\end{tabular}


Table 3 Lipid electrophoresis at age of 2 month 16 days

\begin{tabular}{lll}
\hline Lipoproteins & Result & Reference range \\
\hline Chylomicrons & 4.7 & $0-2 \%$ \\
Beta lipoproteins & 16.5 & $39-70 \%$ \\
Pre-beta lipoproteins & 51.5 & $5-22 \%$ \\
Alpha Lipoproteins & 27.3 & $23-53 \%$ \\
\hline
\end{tabular}

is a sign of a high level of circulating Chylomicrons and VLDL. "Refrigerator test" was also performed which yielded a creamy layer at the top and clear infranatant [15]. Lipoprotein electrophoresis showed elevated levels of VLDL or Pre-beta lipoproteins 51.5\% (RR 5-22\%) and Chylomicrons $4.7 \%$ (RR 0-2\%) which led to the diagnosis of type V HLP.

Our patient had a very severe hypertriglyceridemia, his TG levels were $31,400 \mathrm{mg} / \mathrm{dl}$ and total cholesterol were $1400 \mathrm{mg} / \mathrm{dl}$ at the age of 1 month and 15 days; he was started Cholestyramine therapy at that age. His lipid profile was repeated at 3 months of age, which showed TGs reduced to $1986 \mathrm{mg} / \mathrm{dl}$ and TC to $105 \mathrm{mg} / \mathrm{dl}$. The endocrinologists have planned to start satins if lipid profile (TGs and VLDL) worsens on the next follow-up.

A case by Manzor et al. in 2015 reported a 10 days old baby girl with symptoms of refusal to feed and irritability. She was a product of 3rd-degree consanguinity, diagnosed based on altered lipid profile which showed total cholesterol of $1236 \mathrm{mg} / \mathrm{dl}$ (reference range $170 \mathrm{mg}$ / dl) and triglycerides of $2132 \mathrm{mg} / \mathrm{dl}$. Genetic testing was not done; statins were started along with dietary modification [16].

Pugni et al. in 2014 described the case of a newborn presenting with severe hypertriglyceridemia $(>10 \mathrm{mmol} /$ L), diagnosed with monogenic lipoprotein lipase deficiency, who benefited by exchange transfusion, as a safe alternative to plasmapheresis, in order to prevent acute pancreatitis in young infants with this condition [17].

The type $\mathrm{V}$ hyperliproteinemia could be related to genetic factors and acquired or environmental factors (i.e. diabetes, drinking, hormonal therapy, certain drugs, myeloma, SLE, lymphoma and etc). The possible explanation for dyslipidemia development in our case was most likely genetic and not related to environmental factors as the patient was otherwise healthy.

Gotoda $\mathrm{T}$ et al. in 2012 stated that environmental factors such as diabetes, drinking hormonal therapy, drugs and myeloma present in only $2 / 3$ of patients with type $\mathrm{V}$ hyperlipoproteinemia, while $1 / 3$ patients does not have these factors [18]. The environmental factors were not present in our patient.

This disorder is caused by mutations in different genes such as LPL, Apo B, APOC2, APOA5, GPIHBP1, and LMF1 genes. These mutations are inherited in an autosomal recessive fashion. Our limitation was that we did not perform genetic testing due to non-availability of these tests in the country and due to the financial constraints associated with sending the samples abroad. As per Gotoda $\mathrm{T}$ et al., the possibility of LPL deficiency is high if the serum TG level is $1500 \mathrm{mg} / \mathrm{dl}$ or higher, the serum total cholesterol level is about 1/10 the serum TG level or lower [18]. Our patient had TG level higher than $1500 \mathrm{mg} / \mathrm{dl}$ and his total cholesterol was lower than 1/ 10. In our case most probable cause of dyslipidemia development is genetic, because he was diagnosed at very young age (1 month and 15 days) there was no any environmental factor involved, furthermore his TC was lower than $1 / 10$ of serum TG, which gives the possibility of LPL deficiency. The Endocrine Society does not recommend routine measurements of these tests for diagnosis of type HLP [19].

A case by Cristina Oana et al. in November 2017 reported a 16-year-old female teenager presenting with severe abdominal pain prominently in the lateral left quadrant, nausea, vomiting and constipation for 2 days. On examination, she had ascites and paralytic ileus. She also had increased level of triglycerides $555.1 \mathrm{mg} / \mathrm{dl}$ with normal total cholesterol of $180.5 \mathrm{mg} / \mathrm{dl}$. Lipoprotein electrophoresis showed low level of alpha-lipoproteins (7.6\%), increased pre-beta lipoproteins (71.2\%), lack of beta-lipoproteins and raised Chylomicrons (21.2\%). They found low level of Apolipoproteins A $(0.82 \mathrm{~g} / \mathrm{L})$, and a normal level of apolipoproteins B. She was diagnosed with type $\mathrm{V}$ hyperlipoproteinemia based on lipoprotein electrophoresis and Apo A [15].

In conclusion the literature and case reports on type $\mathrm{v}$ hyperlipoproteinemia is scarce. Bianshly Rivera et al. in May 2019 stated that there are no specific diagnostic and management guidelines for this disorder due to insufficient number of cases [20]. Therefore, it prompted us to report this case so that our findings could result in timely diagnosis, treatment and dietary modification and help the affected patients live a normal life.

\section{Abbreviations}

FCS: Familial chylomicronemia syndrome; LDL: low density cholesterol; TC: Total cholesterol; TG: Triglycerides; TG/TC: triglycerides to total cholesterol

\section{Acknowledgements}

None.

\section{Authors' contributions}

All authors have read and approved the manuscript and ensure that this is the case. SD identified, diagnosed and wrote the case. TSS critically reviewed the case for intellectual content.

Funding

None.

Availability of data and materials

All relevant data are included in the case. 


\section{Ethics approval and consent to participate}

Case was reported after the approval of Institutional Review Board (IRB)/ Ethical Committee of NIBD Hospital.

\section{Consent for publication}

Written informed consent was obtained from the patient's legal guardian(s) for publication of this case report and images. A copy of the written consent copy is available for review by the Editor-in-Chief of this journal.

\section{Competing interests}

The authors declare that they have no competing interests.

Received: 30 September 2019 Accepted: 4 February 2020

Published online: 11 February 2020

\section{References}

1. Rosenson RS, Brewer HB Jr, Chapman MJ, Fazio S, Hussain MM, Kontush A et al. HDL measures, particle heterogeneity, proposed nomenclature, and relation to atherosclerotic cardiovascular events. EJ Clin Chem. 2011;57(3):392.

2. Feingold KR, Grunfeld C. Introduction to lipids and lipoproteins. South Dartmouth: MDText.com, Inc; 2000.

3. Stone NJ, Robinson JG, Lichtenstein AH, Bairey Merz CN, Blum CB, Eckel RH, et al. ACC/AHA guideline on the treatment of blood cholesterol to reduce atherosclerotic cardiovascular risk in adults: a report of the American College of Cardiology/American Heart Association Task Force on Practice Guidelines. Circulation. 2014;129(Suppl):1-45

4. Scott M, Angela J, Susan T, Elaine Z, Susan A, Becker D, et al. Third Report of the National Cholesterol Education Program (NCEP) Expert Panel on Detection, Evaluation, and Treatment of High Blood Cholesterol in Adults (Adult Treatment Panel III) National Cholesterol Education Program National Heart, Lung, and Blood Institute National Institutes of Health $\mathrm{NIH}$ Publication No. 02-5215; 2002.

5. Brahm A, Hegele R. Hypertriglyceridemia. Nutrients. 2013;5(3):981-1001.

6. Falko JM. Familial Chylomicronemia syndrome: a clinical guide for endocrinologists. Endocr Pract. 2018;24(8):756-63.

7. Rengarajan R, McCullough PA, Chowdhury A, Tecson KM. Identifying suspected familial chylomicronemia syndrome. Proc (Baylor Univ Med Cent). 2018:31(3):284-8.

8. Andres G, Karren RW, Andrew H, Andrea RG, Alan G, Alan B, et al. The burden of familial chylomicronemia syndrome from the patients' perspective. Expert Rev Cardiovasc Ther. 2017;15(11):879-87.

9. Chait, Brunzell JD. Chylomicronemia syndrome. Adv Intern Med. 1992; 37:249-73.

10. Philippe Moulin A, Robert Dufour B, Maurizio Averna C, Marcello Arca D, Angelo $B$, Cefalù $C$, et al. Identification and diagnosis of patients with familial chylomicronemia syndrome (FCS): expert panel recommendations and proposal of an "FCS score". Atherosclerosis. 2018:275:265-72.

11. Stores E, Moulin P, Parhofer KG, Rebours V, Löhr JM. Averna et al.Diagnostic algorithms for familial chylomicronemia syndrome. Atheroscler Suppl. 2017;23:1-7.

12. Rahalkar AR, Giffen F, Har B, Ho J, Morrison KM, Hill J, et al. Novel LPL mutations associated with lipoprotein lipase deficiency: two case reports and a literature review. Can J Physiol Pharmacol. 2009;87(4):151-60.

13. Santamarina FS. The familial chylomicronemia syndrome. Endocrinol Metab Clin N Am. 1998;27(3):551-67.

14. Cox RA, García-Palmieri MR. Clinical methods: the history, physical, and laboratory examinations. 3rd ed. Walker HK, Hall WD, Hurst JW, editors. Boston: Butterworths; 1990

15. Cristina OM, Lorena E, Minodora MO. Type $\mathrm{V}$ hypertriglyceridemia in children, a therapeutic challenge in pediatric a case report and a review of the literature. Clin Case Rep Med. 2017:96(51):e8864.

16. Manzoor S, Wani K, Rashid M, Alaqaband MM, Mustaq S. Familial chylomicronemia syndrome (FCS) in a 10-day-old neonate: a case report. Int J Pediatr. 2015;3(14):449-53.

17. Pugni L, Riva E, Pietrasanta C, et al. Severe hypertriglyceridemia in a newborn with monogenic lipoprotein lipase deficiency: an unconventional therapeutic approach with exchange transfusion. JIMD Rep. 2014;13:59-64

18. Takanari G, Koji S, Takao O, Junji K, Yokoyama S, Shiba MH. Diagnosis and management of type 1and type 5 hyperlipoproteinemia. J Atheroscler Thromb. 2012;19:1-12

19. Berglund L, Brunzell JD, Goldberg AC, Goldberg IJ, Sacks F, Murad MH, et al. Evaluation and treatment of hypertriglyceridemia: an Endocrine Society clinical practice guideline. J Clin Endocrinol Metab. 2012;97(9):2969-89.
20. Bianshly R, Laura O, Carlos P, Natalia W. Recurrent pancreatitis induced by uncontrolled type $V$ hyperlipoproteinemia. J Endocr Soc. 2019; 3(Suppl 1):SUN-056

\section{Publisher's Note}

Springer Nature remains neutral with regard to jurisdictional claims in published maps and institutional affiliations.

\section{Ready to submit your research? Choose BMC and benefit from:}

- fast, convenient online submission

- thorough peer review by experienced researchers in your field

- rapid publication on acceptance

- support for research data, including large and complex data types

- gold Open Access which fosters wider collaboration and increased citations

- maximum visibility for your research: over $100 \mathrm{M}$ website views per year

At BMC, research is always in progress.

Learn more biomedcentral.com/submissions 